\title{
Crystallization and Preliminary X-ray Diffraction of a Halophilic Archaeal Malate Synthase
}

\author{
Geoffrey Thomas ${ }^{\dagger}$, Kenneth Lamlenn ${ }^{\dagger}$, and Bruce R. Howard ${ }^{\star}$ \\ Department of Physical Science \\ Southern Utah University \\ Cedar City, Utah 84720 USA
}

Received: August 10, $2009 \quad$ Accepted: December 2, 2009

\begin{abstract}
Malate synthases found in cells of the halophilic Archaea constitute a third isoform of this important metabolic enzyme, in addition to the well characterized $A$ and $G$ isoforms. They share little sequence similarity with these other two isoforms. Database searches using basic local alignments reveal relationships between isoforms $A$ and $G$, but do not indicate a significant sequence relationship between members of this third isoform and those of isoform $G$, and only a distant relationship with members of isoform $A$. This third isoform, which we propose to call isoform $\mathrm{H}$ (Halophilic archaeal), is also significantly smaller in size: $\sim 100$ residues shorter than isoform $A$, and $\sim 300$ residues shorter than isoform $G$. Representatives of both isoform $A$ and $G$ have been structurally characterized, but no three-dimensional structural information exists for isoform $\mathrm{H}$. Here we report the crystallization and preliminary $\mathrm{X}$-ray diffraction from a crystal form of an $\mathrm{H}$-isoform member, the malate synthase from the halophilic archaeon Haloferax volcanii, originally isolated from the mud of the Dead Sea. This crystal form diffracts well, and is amenable to single crystal $\mathrm{X}$-ray analysis.
\end{abstract}

\section{INTRODUCTION}

Malate synthase is one of two enzymes unique to the glyoxylate cycle, the other being isocitrate lyase [1]. This metabolic pathway has been identified in all three domains of life [2, 3], and allows plants to convert fatty acids to citric acid cycle intermediates, and allows microorganisms to survive on two-carbon compounds such as acetate for a sole carbon source. The glyoxylate cycle has been shown to be important for the virulence of pathogenic organisms such as Mycobacterium tuberculosis and Candida albicans [4, 5], and is therefore a target for antibacterial and antifungal drug development efforts [6].

† These authors contributed equally to this work.

* To whom correspondence should be addressed: e-mail howard@suu.edu
Most organisms in which the glyoxylate cycle exists contain one of two isoforms of malate synthase, either $A$ or $G$, while $E$. coli contains both $[7,8]$. Isoform $A$ (43.3-91.9\% identity among isoform members) and $\mathrm{G}$ (53.2-81.0\% identity) show a distant, but significant, sequence conservation with each other ( 18\% identity for conserved segments) [6]. However, the archaeal isoform of malate synthase (which we will call here isoform $\mathrm{H}$ for Halophilic, archaeal) has been estimated to share lower levels of sequence similarity $(10.2-14.1 \%$ or $10.5-12.0 \%$ identity) with either isoform $A$ or $G$ respectively [9]. While basic local alignment searches of the UniProt database using members of either isoform $A$ or $G$ identify other $A$ and $G$ isoform members as being related, searches using the $H$. volcanii malate synthase $H$ sequence do not identify any of the isoform $G$ malate synthase 
sequences as closely related. A BLAST search indicates instead a closer relationship with $\mathrm{HpcH} / \mathrm{Hpal}$ aldolase $(37 \%$ identity) and the beta chain of citrate lyase (38\% identity). A search of the current UniProt database does however indicate three malate synthase $A$ sequences as being distantly related with an estimated $23 \%$ identity and E-values ranging from 0.29 to 5.4. These three malate synthases were deposited recently and are predicted proteins from the genome sequences of the following organisms: Streptomyces $s p$. SPB74 (UniProt accession number B5GAJ4), Actinosynnema mirum (UniProt accession number C6WEX5), and Kocuria rhizophila (UniProt accession number B2GGL2). This indicates a closer relationship between isoform $\mathrm{H}$ and $\mathrm{A}$ than between isoform $\mathrm{H}$ and $\mathrm{G}$. In addition to the lack of strong sequence similarity, these three isoforms also vary considerably in size: malate synthase $G$ is comprised of $\sim 730$ amino acid residues, malate synthase $A$ of $\sim 530$, and malate synthase $\mathrm{H}$ of only $\sim 430$ residues [9]. One other member of isoform $\mathrm{H}$ has been identified by sequence homology ( $81 \%$ identity) in the genome of Haloarcula marismortui and is predicted to be 435 amino acids in length [10].

Members belonging to both isoforms $G[11,12]$ and $A[6]$ have been structurally characterized using X-ray crystallography and one malate synthase $G$ has also been characterized structurally using NMR [13]. All of these previously determined structures are for enzymes that are found in their native states as monomers. However, there is no three-dimensional structural information for the third class of malate synthase, isoform $\mathrm{H}$. The isoform $\mathrm{H}$ variant encoded by the $a c e B$ gene from Haloferax volcanii which we have crystallized, and report here, is 432 residues in length, has a molecular weight of $48 \mathrm{kDa}$, and has been predicted to form a tetramer based on gelfiltration mobility [2, 9].

In order to investigate the structural relationship of isoform $\mathrm{H}$ with those of $\mathrm{A}$ and
G we have undertaken the present study. Structural determination of a malate synthase $\mathrm{H}$ will allow us to define the structural relationships among these three isoform variants, and therefore better understand evolutionary relationships and how the monomeric malate synthase structures which have been determined previously relate to this multimeric enzyme.

Since both known examples of isoform $\mathrm{H}$ have been found in halophilic archaea, it also offers an opportunity to explore the halophilic adaptation of these enzymes. Malate synthase from $H$. volcanii is most active at a $\mathrm{KCl}$ concentration of $3 \mathrm{M}$ [2]. This is similar to the levels found in cells of a halobacterium species isolated from the Dead Sea which was found to contain $\mathrm{K}^{+}$ concentrations ranging from 3.7 to $5.5 \mathrm{M}$, and $\mathrm{Cl}^{-}$concentrations ranging from 2.3 to 4.2 $\mathrm{M}$ depending on the growth stage of the cultures [14]. These high levels of cellular potassium were measured in cells grown in a medium containing only $\sim 9 \mathrm{mM} \mathrm{K}$, indicating the active accumulation and concentration of potassium ions to high levels within these organisms.

\section{MATERIALS AND METHODS}

\section{a. Cell Culture}

A lyophilized sample of Haloferax volcanii was obtained from the American Type Culture Collection [15]. Cells were grown as previously described [2] in a chemically-defined medium using acetate as a sole carbon source to induce expression of glyoxylate cycle enzymes. The culture media contained $2.14 \mathrm{M} \mathrm{NaCl}, 246 \mathrm{mM}$ $\mathrm{MgCl}_{2}, 29 \mathrm{mM} \mathrm{K}_{2} \mathrm{SO}_{4}, 1.8 \mathrm{mM} \mathrm{CaCl}, 5 \mathrm{mM}$ $\mathrm{NH}_{4} \mathrm{Cl}, 0.5 \mathrm{mM} \mathrm{K}_{2} \mathrm{HPO}_{4}, 0.22 \mu \mathrm{M} \mathrm{CuSO}$, $8.6 \mu \mathrm{M} \mathrm{FeSO}, 1.7 \mu \mathrm{M} \mathrm{ZnSO}_{4}, 2.0 \mu \mathrm{M}$ $\mathrm{MnCl}_{2}, 2.4 \mu \mathrm{M}$ thiamine, $0.4 \mu \mathrm{M}$ biotin and between 12 and $49 \mathrm{mM}$ sodium acetate. The $\mathrm{pH}$ of the media was adjusted to 6.8 using $\mathrm{KOH}$. The cultures were inoculated and grown in a shaking incubator at $37^{\circ} \mathrm{C}$ and $120 \mathrm{rpm}$; progress was monitored by 
measuring the absorbance at $595 \mathrm{~nm}$. After approximately two weeks of growth, the cultures had reached a plateau in their cell density and were harvested by centrifugation at $12,000 \mathrm{~g}(8,000 \mathrm{rpm})$ in a 4 $x 1$ liter Fiberlite rotor and cell pellets were stored at $-80^{\circ} \mathrm{C}$.

\section{b. Protein Purification}

Protein purification was carried out as previously described [2] with slight modifications; all steps were carried out at 4 ${ }^{\circ} \mathrm{C}$. The frozen pellets were resuspended in lysis buffer consisting of $2.5 \mathrm{M}\left(\mathrm{NH}_{4}\right)_{2} \mathrm{SO}_{4}$ and $50 \mathrm{mM} \mathrm{Na}_{3} \mathrm{PO}_{4}, \mathrm{pH}$ 6.6. Cells were lysed by sonication using a Fisher Scientific Model 100 sonic dismembrator. The cellular debris were pelleted by centrifugation, and the cell lysate was loaded onto a phenylsepharose column (Pharmacia), preequilibrated with lysis buffer. The bound proteins were eluted using a linear gradient from $2.5 \mathrm{M}$ to $0.5 \mathrm{M}\left(\mathrm{NH}_{4}\right)_{2} \mathrm{SO}_{4}$. Fractions containing malate synthase activity were pooled and loaded onto a DEAE-cellulose column (Whatman) equilibrated with $2.5 \mathrm{M}$ $\left(\mathrm{NH}_{4}\right)_{2} \mathrm{SO}_{4}$ and $50 \mathrm{mM} \mathrm{Na} 3 \mathrm{PO}_{4}, \mathrm{pH}$ 6.6. Bound proteins were eluted using a linear gradient into buffer containing $2.0 \mathrm{M} \mathrm{NaCl}$ and $50 \mathrm{mM} \mathrm{Na}_{3} \mathrm{PO}_{4}, \mathrm{pH}$ 6.6. Fractions containing the highest levels of malate synthase activity were pooled and concentrated by ultrafiltration (Amicon Ultra15, Ultracel-10 from Millipore) to a total volume of $1 \mathrm{~mL}$, and loaded onto a Sephacryl S-300 column (Pharmacia), equilibrated with $2 \mathrm{M} \mathrm{KCl}$ and $50 \mathrm{mM}$ Tris. $\mathrm{HCl} \mathrm{pH} \mathrm{8.0,} \mathrm{for} \mathrm{gel} \mathrm{filtration.} \mathrm{Again,} \mathrm{the}$ fractions containing the highest levels of malate synthase activity were pooled and concentrated using ultrafiltration to a final concentration of $7 \mathrm{mg} / \mathrm{mL}$. Protein concentration was calculated by measuring the absorbance at $280 \mathrm{~nm}$, using an extinction coefficient of $53400 \mathrm{M}^{-1} \mathrm{~cm}^{-1}$ (ProtParam, ExPASy). Sodium dodecyl sulfate polyacrylamide gel electrophoresis
(SDS PAGE) was used to monitor the purification procedure.

c. Assay of Enzyme Activity

Malate synthase activity was measured by following the loss of absorbance at $232 \mathrm{~nm}$ due to the enzymatic cleavage of the thioester bond in acetyl-CoA during the reaction as previously described $[11,16]$, but including $3 \mathrm{M} \mathrm{KCl}$ [2]. The reaction conditions were $0.34 \mathrm{mM}$ acetylCoA, $1.1 \mathrm{mM}$ glyoxylate, $20 \mathrm{mM}$ Tris $\mathrm{pH} 8.0$, $2 \mathrm{mM}$ EDTA, $3 \mathrm{M} \mathrm{KCl}$, and $5 \mathrm{mM} \mathrm{MgCl}_{2}$. The reaction was initiated by the addition of $10 \mu \mathrm{L}$ of enzyme solution into a $1 \mathrm{~mL}$ total reaction volume. The progress of the reaction was monitored at $232 \mathrm{~nm}$ using an Agilent model $8453 \quad$ UV/Vis spectrophotometer.

\section{d. Crystallization}

Crystals were grown at room temperature using the vapor diffusion method in sitting drops. Sparse-matrix crystal screening using the Crystal Screen Cryo kit (Hampton Research) was used for initial crystallization experiments [17]. This kit contains $10 \mathrm{~mL}$ samples of 50 unique solutions containing various salts, buffers and precipitants. In addition, one of a number of different cryoprotectants is present. These 50 buffer solutions were used as "well solutions" in our crystallization trays. The process of vapor diffusion was used to cause a controlled precipitation of the protein. The protein solution contained Haloferax volcanii malate synthase at 7 $\mathrm{mg} / \mathrm{mL}, 13 \mathrm{mM} \mathrm{MgCl} 2,3 \mathrm{mM}$ glyoxylate, 50

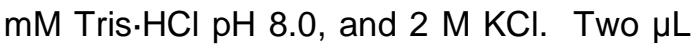
of this protein solution was mixed with an equal amount of each well solution and allowed to equilibrate through vapor diffusion with a $500 \mu \mathrm{L}$ reservoir of that same well buffer. Because of the 1:1 mixing with well solution, the protein in the drop was initially $3.5 \mathrm{mg} / \mathrm{mL}$-half the concentration of the stock solution. For the 
same reason, the precipitant from the well solution was also diluted to half the original concentration. Under these conditions (ideally), the protein would remain soluble. The drops were allowed to equilibrate at room temperature with a much larger amount $(\sim 125 \mathrm{x})$ of well solution, until precipitation of the protein occurred. We screened these 50 conditions visually using a stereomicroscope.

e. X-ray diffraction

Crystals were transported to the laboratory of Dr. Chris Hill at the University of Utah, School of Medicine in Salt Lake City, Utah. The crystals, which were grown in cryo-protected buffer, were each suspended in a nylon loop and plunged into a bath of liquid nitrogen to freeze the crystal in vitreous ice. Data were collected at a temperature of $100 \mathrm{~K}$ using Copper $\mathrm{Ka}$ radiation produced by a Rigaku $007 \mathrm{HF}$ rotating anode generator with Osmic confocal X-ray optics, on an R-axis IV image plate detector. Diffraction data were indexed, integrated and scaled using the HKL2000 software package [18].

\section{RESULTS}

After the purification procedure we were able to estimate the purity of the Haloferax volcanii malate synthase by running an 8$25 \%$ gradient SDS PAGE (Figure 1). This allowed us to estimate the concentration of malate synthase compared to those of contaminating proteins. Due to the limited amount of enzyme present in this environmental strain, silver staining was required to visualize the protein on denaturing gels during the purification procedure (Figure 1). Based on the dilution series in lanes 6, 7 and 8 (3, 9 and 27-fold dilutions of lane 4 respectively), we estimate

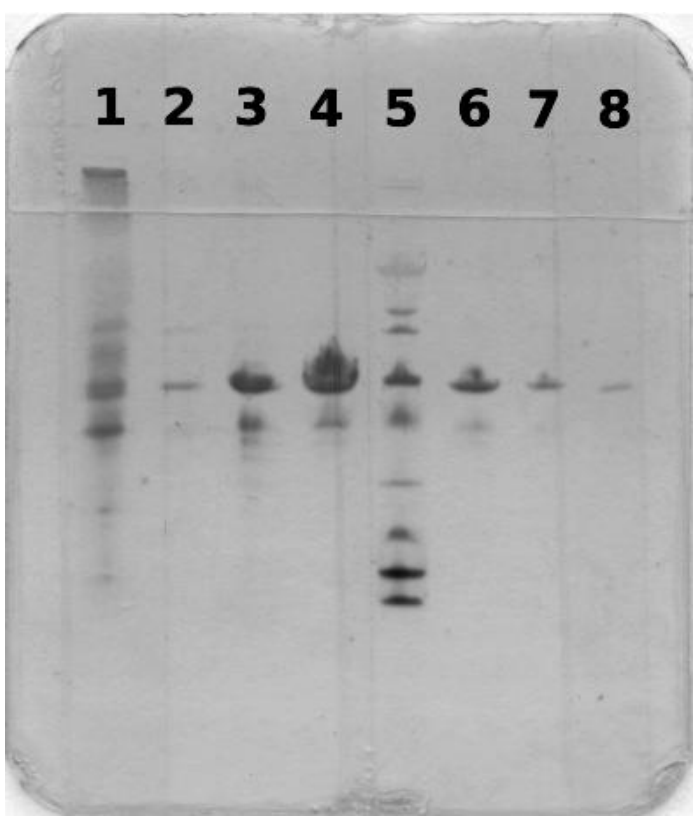

Figure 1. Silver-stained SDS PAGE following the various steps of the of the purification protocol. Lane 1: Cell lysate. Lane 2: Elution peak from phenylsepharose column. Lane 3: Concentrated pool from DEAE column. Lane 4: Final purification product, concentrated to $7 \mathrm{mg} / \mathrm{mL}$. Lane 5 : Broad range protein molecular weight standards (Bio-Rad; $200 \mathrm{kDa}, 116.25 \mathrm{kDa}$, $97.4 \mathrm{kDa}, 66.2 \mathrm{kDa}, 45 \mathrm{kDa}, 31 \mathrm{kDa}, 21.5$ $\mathrm{kDa}, 14.4 \mathrm{kDa}$, and $6.5 \mathrm{kDa}$ ). Lanes 6-8: Dilutions of final purification product. Lane 6: $\sim 2.3 \mathrm{mg} / \mathrm{mL}$. Lane $7: \sim 0.8 \mathrm{mg} / \mathrm{mL}$. Lane 8: $\sim 0.26 \mathrm{mg} / \mathrm{mL}$.

the purified malate synthase to be $\sim 90 \%$ pure. As expected, $H$. volcani malate synthase runs $\sim 65 \mathrm{kDa}$ due to the excess of acidic residues in the enzyme [9]. Average yield of the final, purified malate synthase was $0.5 \mathrm{mg}$ per liter of cell culture.

Initial crystals of malate synthase from Haloferax volcanii were identified using PEG 4000 as the precipitant. The well buffer contained $0.17 \mathrm{M}$ ammonium acetate, 


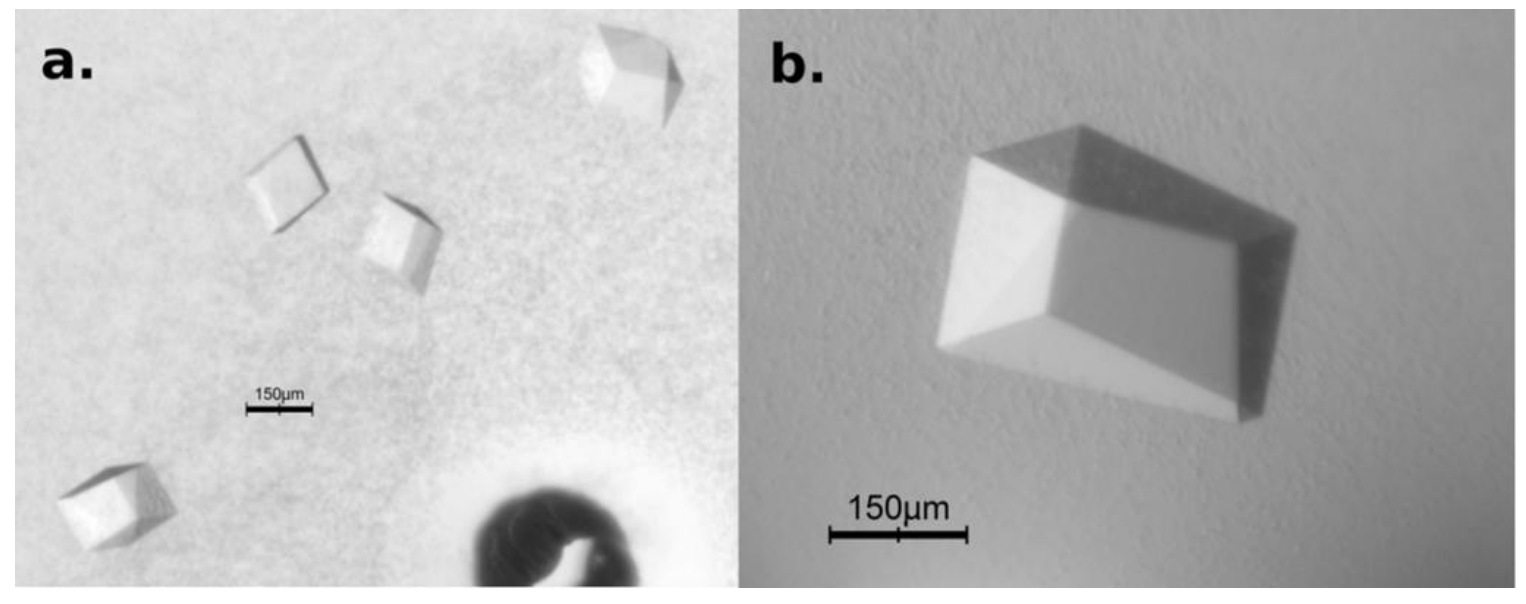

Figure 2. Haloferax volcanii malate synthase crystals under two magnifications (a and b).

$25.5 \% \mathrm{w} / \mathrm{v}$ PEG 4000, 15\% glycerol, and $0.085 \mathrm{M}$ sodium acetate trihydrate at a $\mathrm{pH}$ of 4.6. Optimization was carried out using PEG 4500. Single crystals were found to grow across a pH range from 4.4 to 5.0 , and a concentration range of PEG 4500 between 24.5 and $27 \%$ w/v (Figure 2). Malate synthase from $H$. volcanii crystallizes in the rhombohedral space group R32 with unit cell dimensions $\mathrm{a}=\mathrm{b}=$ $156.37 \AA, c=141.46 \AA, \alpha=\beta=90^{\circ}, y=$ $120^{\circ}$. The crystals diffract sufficiently well to permit a crystallographic analysis and a structural determination of this enzyme. Figure 3 shows an example of the diffraction from one of these crystals, which diffracted to a resolution beyond 3 angstroms. A native dataset was collected to $2.7 \AA$ (Table 1). For a discussion of $\mathrm{X}$-ray diffraction theory and practice please see references [19] and [20].

\section{DISCUSSION}

The purification procedure used in this experiment, based on a published protocol [2], was carried out with two modifications. The first column was described in the published protocol as a Sepharose-4B column, which is a generic matrix to which any molecule with a primary amine may be covalently attached. Based on the loading and elution buffers used for

\begin{tabular}{|c|c|}
\hline Resolution & $\begin{array}{c}30-2.70 \AA \\
(2.80-2.70 \AA)\end{array}$ \\
\hline $\mathrm{R}_{\text {merge }}(\%)$ & $9.0(38.3)$ \\
\hline $\begin{array}{l}\text { Average signal to noise } \\
\text { Ratio, I/ } \sigma \mathrm{I}\end{array}$ & $14.2(4.2)$ \\
\hline Completeness (\%) & $100(100)$ \\
\hline $\begin{array}{l}\text { Number of unique } \\
\text { reflections }\end{array}$ & 18,255 \\
\hline $\begin{array}{l}\text { Number of observed } \\
\text { reflections }\end{array}$ & 104,473 \\
\hline \multicolumn{2}{|c|}{$\begin{array}{l}\text { Values in Parentheses are for the high- } \\
\text { resolution shell. }\end{array}$} \\
\hline \multicolumn{2}{|c|}{$\begin{array}{l}\mathrm{R}_{\text {merge }}(\%)=100 \times \sum \mathrm{hkl}|\mathrm{I}-<\mathrm{I}>| / \sum \mathrm{hkl}(\mathrm{I}) \text {, } \\
\text { where } \mathrm{I} \text { is the observed intensity, and }<\mathrm{I}> \\
\text { is the average intensity for multiple } \\
\text { observations of symmetry related } \\
\text { reflections. }\end{array}$} \\
\hline
\end{tabular}

Table 1. X-ray Data Collection Statistics.

this column, we assumed the Sepharose-4B column in this case was a reverse phase column and therefore used a phenylsepharose matrix for this initial chromatography step, which worked well (Figure 1). The second modification to the published protocol was the use of a different buffer for the S-300 sizing column. We

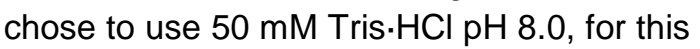
final chromatography step. The Tris buffer replaced the phosphate buffer used in the 


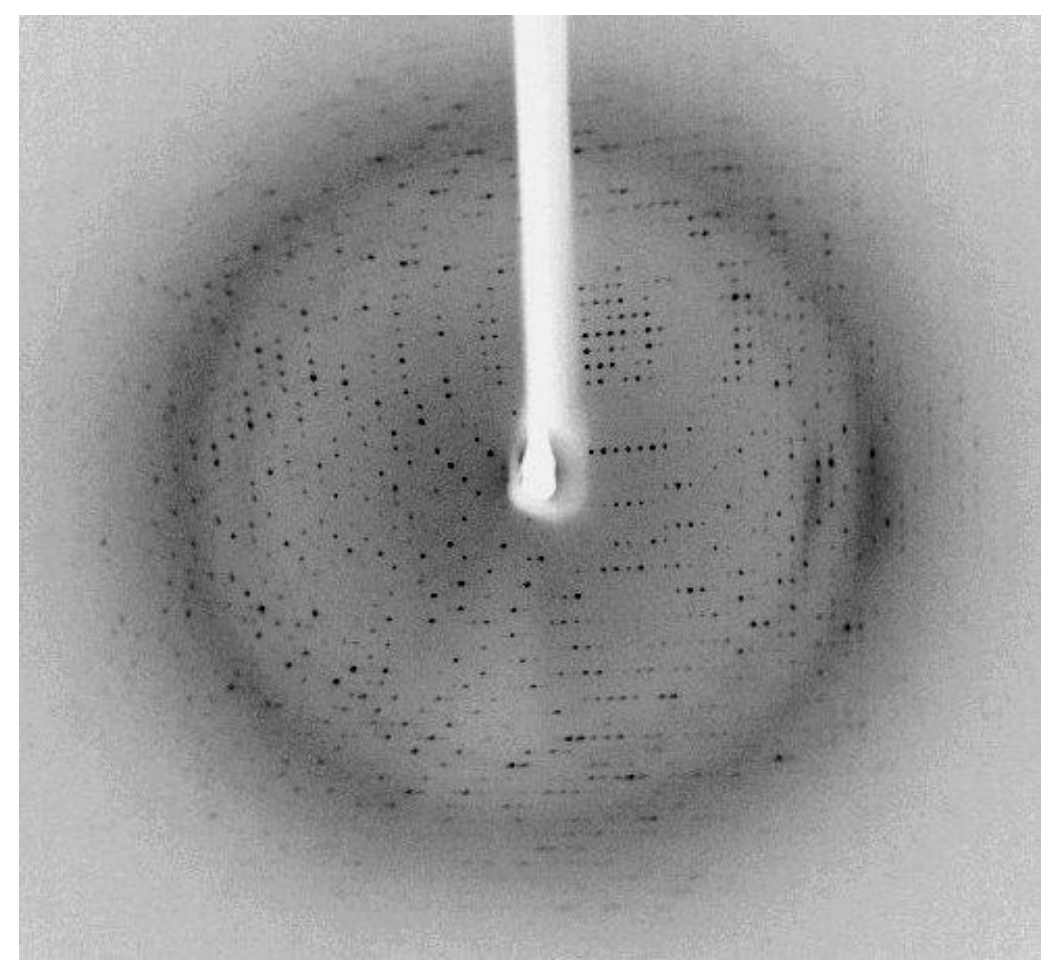

Figure 3. X-ray diffraction from one of the $H$. volcanii malate synthase crystals measuring $\sim 150$ $\mu \mathrm{m} \times 200 \mu \mathrm{m} \times 100 \mu \mathrm{m}$. The exposure time was 10 minutes with a $0.5^{\circ}$ oscillation angle. The edge of the detector corresponds to a resolution of approximately $2 \AA$.

published protocol, in order to avoid potential precipitation problems with magnesium ions which are required for the enzymatic activity [2].

Protein crystals contain significant solvent channels surrounding protein molecules in the crystal lattice. A survey of the percentage of crystal volume occupied by solvent in protein crystals was first carried out in 1968 [21]. A more recent statistical analysis of the crystal structures deposited in the Protein Data Bank (PDB) [22] reveals a wide distribution of values ranging from $\sim 26 \%$ to $\sim 87 \%$ solvent, with a mean of $54 \%$, a median of $51 \%$ and a mode of $47 \%$ [23]. The crystals reported here must contain either one or two protein molecules per asymmetric unit because the volume occupied by three molecules would be larger than the volume of the asymmetric unit itself. Based on the symmetry of these crystals, the volume of the unit cell $(2.992 x$ $10^{6} \AA^{3}$ ) and the size of the mature enzyme with the $\mathrm{N}$-terminal methionine removed $(47,915 \mathrm{Da})$ [9], we can calculate the probable number of molecules in the asymmetric unit of the crystal using the Matthews coefficient $\left(V_{M}\right)$ [21]. Considering the solvent content distribution of the 15,641 protein crystal structures deposited in the PDB by 2002 combined with the observed diffraction limit of our native data set, the most likely number of molecules in the asymmetric unit is one $(89.75 \%$ probability) which corresponds to a solvent content of $64.54 \%$ and $a V_{M}$ of $3.47 \AA^{3} / \mathrm{Da}[23,24]$. If there is just a single molecule per asymmetric unit, this would preclude the existence of a tetramer as the biological unit as has been reported [9]. Instead, the threefold symmetry axis in the crystallographic data implies a trimeric state for the native enzyme. Diffraction data from these crystals would be consistent with the initial report [2] that the native state of the enzyme is a trimer, although this report was based on a 
mistaken estimate of $67 \mathrm{kDa}$ for the mass of individual subunits due to slower migration on an SDS PAGE, coupled with an estimated $200 \mathrm{kDa}$ for the native enzyme from gel filtration chromatography.

In addition to the malate synthase $\mathrm{H}$ from Haloarcula marismortui [10], there are also four other protein candidates in the database which are very similar in length and sequence to the $H$. volcanii malate synthase. Each of these four candidates is found in a different halophilic archaeal species. Although these predicted proteins have been classified as other types of enzymes by authors of genome sequence publications, the high level of sequence identity with the $H$. volcanii malate synthase suggests that they may have been misclassified. The malate synthase from Haloarcula marismortui is comprised of 435 amino acids in length and is $81 \%$ identical in sequence (Blast algorithm with BLOSUM-62 matrix, UniProt). By comparison, the citrate lyase beta subunit from Halogeometricum borinquense DSM 11551 [25], UniProt accession number C1VCA0, is 434 amino acids in length and is $80 \%$ identical in sequence. The Citryl-CoA lyase from Haloquadratum walsbyi (strain DSM 16790) [26], UniProt accession number Q18JF9, is 435 residues in length and is $78 \%$ identical in sequence. The homlog to citryl-CoA lyase from Natronomonas pharaonis (strain DSM 2160 / ATCC 35678) [27], UniProt accession number Q3INJ7, is 436 residues and $76 \%$ identical. And the $\mathrm{HpcH} / \mathrm{Hpal}$ aldolase from Natrialba magadii ATCC 43099 [28], UniProt accession number B9ZF01, is 441 residues in length and is $73 \%$ identical. The similar sizes along with this high level of sequence identity suggest the possibility that these four predicted proteins may have been annotated incorrectly in these genomic sequencing efforts, and they may actually represent additional members of the malate synthase $\mathrm{H}$ isoform.

\section{ACKNOWLEDGEMENTS}

We thank Dr. Chris Hill at the University of Utah for the generous use of his X-ray diffraction instrument. We also extend thanks to Dr. Frank Whitby and Dr. Heidi Schubert at the University of Utah for their assistance with data collection. We thank Bryant Anderson, Richard Warner and Tyler Sherman for working out some of the details of the growth conditions for $H$. volcanii cultures, and thank James Clark and Kelsey Allen for working out initial steps of the purification protocol. We would also like to thank the Provost Faculty Development Grant program at Southern Utah University for generous financial support of this project.

\section{REFERENCES}

1. Kornberg, H.L. and Krebs, H.A., (1957). Synthesis of cell constituents from C2units by a modified tricarboxylic acid cycle. Nature. 179, 988-991.

2. Serrano, J.A., Camacho, M., and Bonete, M.J., (1998). Operation of glyoxylate cycle in halophilic archaea: presence of malate synthase and isocitrate lyase in Haloferax volcanii. FEBS Lett. 434, 13-16.

3. Kondrashov, F.A., Koonin, E.V., Morgunov, I.G., Finogenova, T.V., and Kondrashova, M.N., (2006). Evolution of glyoxylate cycle enzymes in Metazoa: evidence of multiple horizontal transfer events and pseudogene formation. Biol Direct. 1, 31.

4. McKinney, J.D., Höner zu Bentrup, K., Muñoz-Elías, E.J., Miczak, A., Chen, B., Chan, W.T., Swenson, D., Sacchettini, J.C., Jacobs, W.R. Jr., and Russell, D.G., (2000). Persistence of Mycobacterium tuberculosis in macrophages and mice requires the glyoxylate shunt enzyme isocitrate lyase. Nature. 406, 735-738.

5. Lorenz, M.C. and Fink, G.R., (2001). The glyoxylate cycle is required for fungal virulence. Nature. 412, 83-86. 
6. Lohman, J.R., Olson, A.C., and Remington S.J., (2008). Atomic resolution structures of Escherichia coli and Bacillus anthracis malate synthase $A$ : comparison with isoform $G$ and implications for structure-based drug discovery. Protein Sci. 17(11), 19351945.

7. Falmagne $\mathrm{P}$, Vanderwinkel $\mathrm{E}$, and Wiame JM., (1965). Demonstration of 2 malate synthases in Escherichia Coli. Biochim Biophys Acta. 99, 246-258.

8. Molina, I., Pellicer, M., Badia, J., Aguilar, J., and Baldoma, L., (1994). Molecular characterization of Escherichia coli malate synthase $G$. Differentiation with the malate synthase A isoenzyme. Eur. J. Biochem. 224, 541-548.

9. Serrano, J.A. and Bonete, M.J., (2001). Sequencing, phylogenetic and transcriptional analysis of the glyoxylate bypass operon (ace) in the halophilic archaeon Haloferax volcanii. Biochim Biophys Acta. 1520, 154-162.

10. Baliga, N.S., Bonneau, R., Facciotti, M.T., Pan, M., Glusman, G., Deutsch, E.W., Shannon, P., Chiu, Y., Weng, R.S., Gan, R.R., Hung, P., Date, S.V., Marcotte, E., Hood, L., and Ng, W.V., (2004). Genome sequence of Haloarcula marismortui: a halophilic archaeon from the Dead Sea. Genome Res. 14, 2221-2234.

11. Howard, B. R., Endrizzi, J. A., and Remington, S. J., (2000). Crystal structure of Escherichia coli malate synthase $G$ complexed with magnesium and glyoxylate at $2.0 \AA$ resolution: mechanistic implications. Biochemistry. 39,3156-3168.

12. Smith, C. V., Huang, C. C., Miczak, A., Russell, D. G., Sacchettini, J. C., and Höner zu Bentrup K., (2003). Biochemical and structural studies of malate synthase from Mycobacterium tuberculosis. J Biol Chem. 278, 17351743.

13. Grishaev A, Tugarinov V, Kay LE, Trewhella J, Bax A., (2008). Refined solution structure of the $82-k D a$ enzyme malate synthase $G$ from joint NMR and synchrotron SAXS restraints. J. Biomol. NMR 40(2), 95-106.

14. Ginzburg, M., Sachs, L., and Ginzburg, B.Z., (1970). Ion Metabolism in a Halobacterium. J Gen Physiol. 55(2), 187-207.

15. American Type Culture Collection (ATCC). P.O. Box 1549, Manassas, VA 20108, USA. http://www.atcc.org/

16. Eggerer, H. and Klette, A., (1967). On the catalysis principle of malate synthase. Eur. J. Biochem. 1, 447-475.

17. Hampton Research, 34 Journey, Aliso Viejo, CA 92656-3317. http://www.hamptonresearch.com/

18. Otwinowski, Z. \& Minor, W., (1997). Processing of $X$-ray diffraction data collected in oscillation mode. Methods Enzymol. 276, 307-327.

19. Rhodes, G., (2000). Crystallography Made Crystal Clear, $2^{\text {nd }}$ Ed., Academic Press 24-28 Oval Road, London NW17X, UK.

20. Stout, G. H. and Jensen, L. H., (1989). X-ray Structure Determination, A Practical Guide, John Wiley \& Sons, Inc.

21. Matthews, B.W., (1968) Solvent content of protein crystals, J. Mol. Biol. 33, 491497.

22. The Protein Data Bank, http://www.rcsb.org/pdb

23. Kantardjieff, K. A. and Rupp, B., (2003) Matthews coefficient probabilities: Improved estimates for unit cell contents of proteins, DNA, and protein-nucleic acid complex crystals, Protein Sci. 12, 1865-71.

24. Matthews Probability Calculator at http://www.ruppweb.org/Mattprob/

25. Lucas S., Copeland A., Lapidus A., Glavina del Rio T., Dalin E., Tice H., Bruce D., Goodwin L., Pitluck S., Kyrpides N., Mavromatis K., Ivanova N., Markowitz V., Cheng J.-F., Hugenholtz P., Woyke T., Wu D., Tindal B., Klenk H.-P., Eisen J.A. The draft genome of Halogeometricum borinquense DSM 
11551. Submitted (FEB-2009) to the EMBL/GenBank/DDBJ databases.

26. Bolhuis H., Palm P., Wende A., Falb M., Rampp M., Rodriguez-Valera F., Pfeiffer F., Oesterhelt D., (2006). The genome of the square archaeon Haloquadratum walsbyi: life at the limits of water activity. BMC Genomics 7, 169-169.

27. Falb M., Pfeiffer F., Palm P., Rodewald K., Hickmann V., Tittor J., Oesterhelt D., (2005). Living with two extremes: conclusions from the genome sequence of Natronomonas pharaonis. Genome Res. 15, 1336-1343.

28. Lucas S., Copeland A., Lapidus A., Glavina del Rio T., Tice H., Bruce D., Goodwin L., Pitluck S., Larimer F., Land M.L., Hauser L., Maupin-Furlow J.A. Sequencing of the draft genome and assembly of Natrialba magadii ATCC 43099. Submitted (JAN-2009) to the EMBL/GenBank/DDBJ databases.

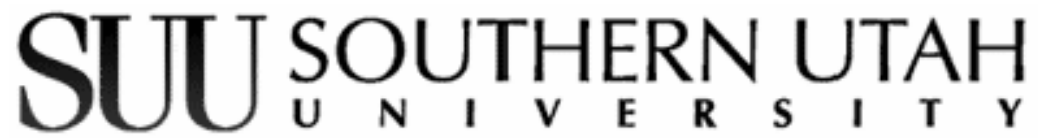

Through its more than 109 year history, Southern Utah University has evolved from a teacher training institution to its current role as a comprehensive, regional university offering graduate, baccalaureate, associate and technical programs. SUU places students first by featuring personalized and participative classes, combined with competent, qualified and supportive faculty, staff and administration. http://www.suu.edul
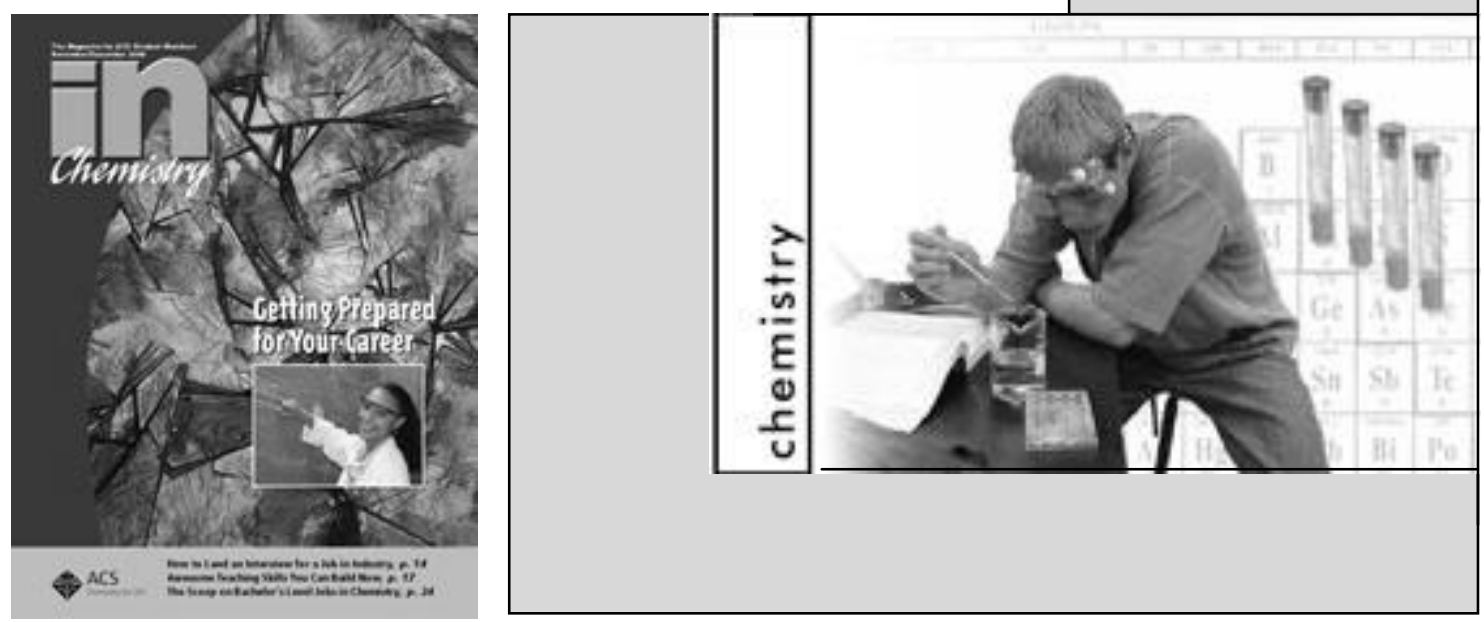


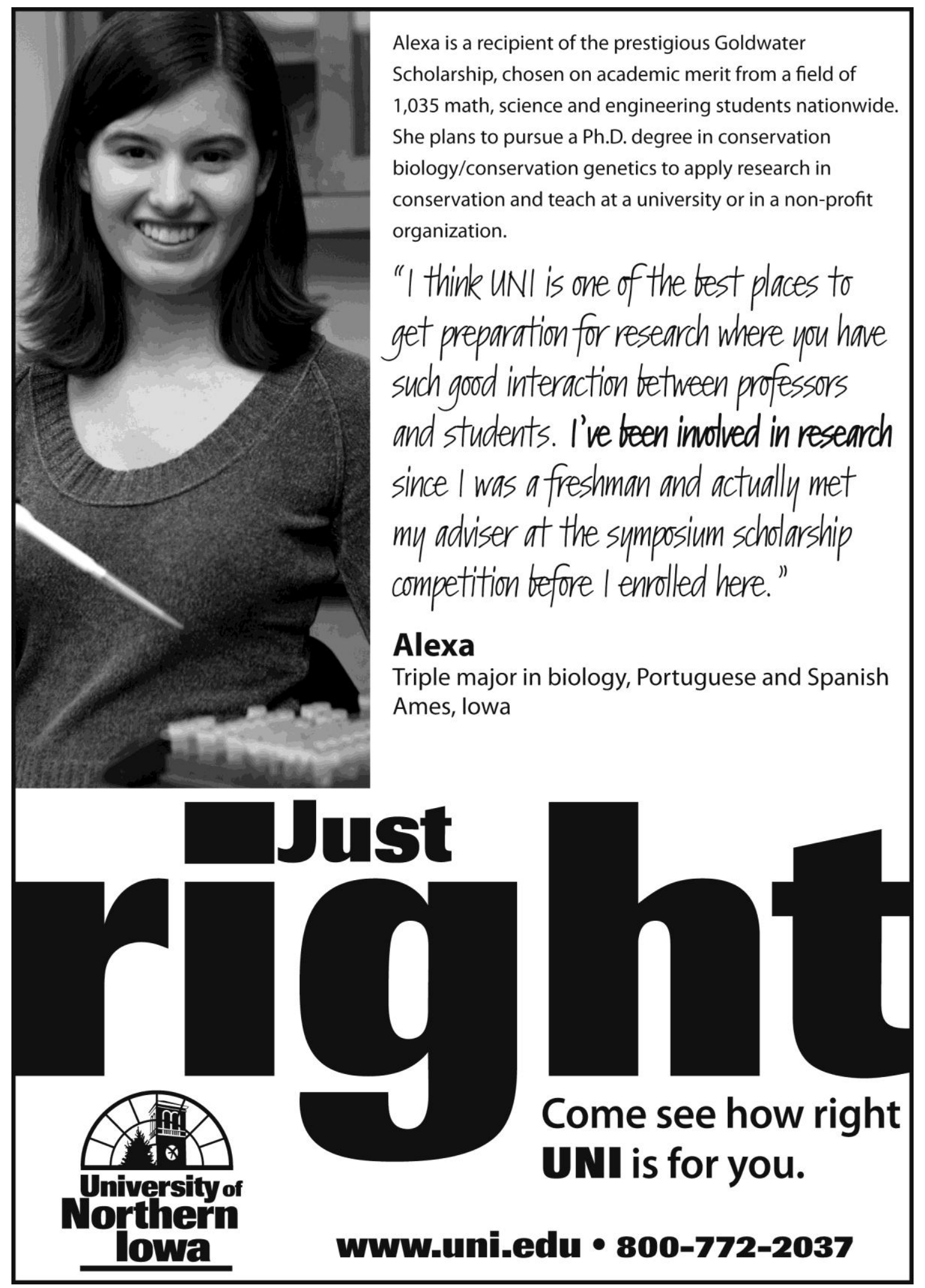

